\title{
Effects of Sowing Date on Sunflower (Helianthus annuus) Damage by Pachnoda interrupta (Coleoptera: Scarabaeidae) and an Economic Threshold Levels for Its Management at Maiduguri, Sudan Savannah Ecological Zone of Nigeria
}

\author{
Abdullahi G. ${ }^{1}$, B. M. Sastawa ${ }^{2} \&$ Shehu A. ${ }^{3}$ \\ 1 Department of Crop Protection, School of Agriculture and Agricultural Technology, Modibbo Adama \\ University of Technology, Nigeria \\ ${ }^{2}$ Department of Crop Protection, Faculty of Agriculture, University of Maiduguri, Nigeria \\ ${ }^{3}$ Department of Agricultural Production Technology, Yobe State College of Agriculture, Nigeria \\ Correspondence: Abdullahi G., Department of Crop Protection, School of Agriculture and Agricultural \\ Technology, Modibbo Adama University of Technology, Nigeria. E-mail: gatsaranyi@yahoo.com
}

Received: June 21, 2012 Accepted: February 20, 2013 Online Published: March 5, 2013

doi:10.5539/sar.v2n3p1 URL: http://dx.doi.org/10.5539/sar.v2n3p1

\begin{abstract}
Pachnoda interrupta is one of the head-infesting insect pests of sunflower in Maiduguri. Two separate field experiment(one each for sowing date effect and threshold level) were conducted to investigate the influence of sowing date on damage and yield loss by P. interrupta on sunflower and the economic threshold level for its control in Maiduguri. The result for influence of sowing date experiment shows that percentage incidence of infestation was highly significant on sunflower sown on the $5^{\text {th }}$ July than other planting date except that of $26^{\text {th }}$ July. Significantly lower damage was recorded on sunflower sown on $19^{\text {th }}$ July than those on the $5^{\text {th }}$ and grain yield loss was also significantly higher on $26^{\text {th }}$ July sowings than all other dates. The results for economic threshold level experiment indicated that 2.38 and 2.36 beetles/head were the economic threshold level for flowing and milky grain stage respectively and there was a 1:4.9 cost: benefit ratio/ ha. This means that there is a $20 \%$ return for every unit of inputs. The result implies that $19^{\text {th }}$ of July is the best planting date to reduce infestations, damage and yield loss from P. interrupta in Maiduguri and artificial control measures should be initiated when there are 1.9 to 2.0 beetles/plant.
\end{abstract}

Keywords: sowing date, sunflower, Pachnoda interrupta, Coleoptera, economic threshold level, management

\section{Introduction}

Sunflower is one of the most important oil crops in most countries of world over (Abdou et al., 2011). It is the second largest oil producing crop of the world (Garret, 1978) and is currently produced in commercial quantities since the early 80's in almost twenty countries (Waalwijk et al., 1989). Sunflower seed produced is been utilized among others for oil extraction (Yayock et al., 1988).

The oil extracted from sunflower seed is a good source of vegetable oil for cooking, manufacture of margarine, paints, soap and other cosmetics (Bamgboye \& Adejumo, 2007). The whole seeds, and even the cakes are also known to be a potential good sources of food and feeds for humans and animals respectively (Oholson, 1992).

In Nigeria there is the need to give great emphasis to this crop to reduce the gap in oil production (Oholson, 1992), especially because of its drought tolerance and suitability to wide range of soil conditions (Abdou, 2011). However, certain factors are known to have some influence on the performance of sunflower. Prominent among these is sowing date (Abdou, 2011). The yield of sunflower is also highly reduced due to incidence of pests and diseases.

The sunflower beetle Pachnoda interrupta is one of the major insects pests with great notoriety for attacking the crop (FAO, 1972). It was first reported attacking sunflower on the African subcontinent at Ethiopia in 1992 (Ethiopian Humanitarian update, 2000). The adult of $P$. interrupta feeds on the flowers and milky grain seeds of sunflower and serious damage have been reported to occur where 2-3 beetles are present/plant (Isobe, 1992; 
Abdou, 2011). Information on the effects of sowing date on the damage of sunflower by P. interrupta and the threshold levels for its control especially in this part of the country is lacking in literature. The objectives of the study were to: assess the effect of sowing date on sunflower yield in the face of damage by $P$. interrupta, determine its economic injury level, and the profitability of sunflower productions in the face of $P$. interrupta infestations.

\section{Materials and Methods}

\subsection{Study Site}

The studies were carried out at the University of Maiduguri Teaching and Research farm (Latitude $11^{\circ} 5^{\prime} \mathrm{N}$ and Longitude $13^{\circ} 5^{\prime}$ ) during 2007 cropping seasons. Two separate experiment to determine the, influence of sowing dates on P. interrupta damage on sunflower and economic threshold level for control of same were conducted.

\subsection{Effects of Sowing Date Experiment}

A total of experimental field of $16 \times 21 \mathrm{~m}$ was used for this experiment. Twelve fields measuring $4 \times 4 \mathrm{~m}$ each were prepared out of the total experiment are and laid out in randomized complete block design giving three blocks of four plot each.

Sowing was done in July with a predetermined interval of one week each using a single variety (Funtua) of sunflower commencing from $15^{\text {th }}$ of July. Four seeds were sown per hole at a spacing of $1 \times 1 \mathrm{~m}$ and were later thinned to two plants per stand 3 weeks after germination. Routine agronomic practices were regularly carried out throughout the experimental period.

Counting of adult Pachnoda interrupta infesting the sunflower heads were carried out once every week for a period of eight weeks starting from the booting stage and recorded accordingly. Days to $50 \%$ heading were also recorded.

\subsection{Data Analysis}

Data generated from the experiment were analyzed thus:

Mean number of insects per plots $=$ Total number of insect per plot $/$ Total number of plant per plot

Mean percentage incidence $=$ Number of attacked plants per plot $/$ Total number of plants per plot $\mathrm{x} 100$

Percentage grain Damage $=$ Area of head damage per plant $/$ Total area of head of the plant $x 100$

Grain yield $(\mathrm{kg}$ per ha) $=$ Yield per plant pockets $(\mathrm{kg})$ x Number of harvestable plants pocket per ha

\subsection{Economic Threshold Level Experiment}

Total experimental area of $8.4 \times 8.6 \mathrm{~m}$ was used for this experiment. This was dived into three sub-blocks measuring $2.2 \times 8.6 \mathrm{~m}$. Planting was done on July $7^{\text {th }}$ at an intra and inter spacing of $40 \times 60 \mathrm{~cm}$ respectively using a single sunflower variety (Record). The seed were obtained from the department of Crop Protection, University of Maiduguri.

Copper cages enclosed in mosquito nets and measuring $1 \mathrm{~m}$ long and $0.4 \mathrm{~mm}$ diameter were used as exclusion cages. Six population levels of $0.1,2,3,4$, and 5 beetles/cage/ head were maintained in the cages. Each population level represent a treatment and was replicated 3 times. The entire experiment was laid out in randomized complete block design (RCBD) consisting of six treatments replicated three time both at milky and dough grain stages. Infestations were done at two different stages (Flowering and milky grain stages) in the phonological stages of the plant.

Infestations for the flowering stage were carried out on September $11^{\text {th }} 2007$ (a week after flower has began to set). Infestations for milky grain stage were carried out on the $29^{\text {th }}$ of September.

Area damaged at each stage were measured and recorded. The cages and adult beetles were removed on September $28^{\text {th }}$ for flowering stage infestations and on $20^{\text {th }}$ October when the grain become dough for milky grain stage infestations. Grain yield were later calculated.

\subsection{Statistical Analysis}

Data collected were transformed using square root $\sqrt{\mathrm{x}}+1$ to remove dependency of the Variances on the means. The transformed values were then later subjected to the Analysis of Variance (ANOVA). Least significant difference (LSD) were later calculated for each set of experiment using GENSTAT statistical package, version 9.2 for windows $\left(9^{\text {th }}\right.$ edition) released 2007. Regression analysis was carried out to determine yield loss/insects. Economic injury level, gain threshold and cost returns (gross margin analysis) were also calculated thus; 
Economic injury level $=$ Gain threshold $/$ Loss per insect $\mathrm{x}$ amount of loss avoided

Gain threshold $=$ Cost $(\mathrm{N})$ of insecticides/Value $(\mathrm{N})$ of crop per ha

Cost and returns (gross margin analysis). This was determined based on cost of production and returns from sales of sun flower seeds. The cost of production included the cost of all inputs such as fertilizer, seeds, insecticide, weeding, harvesting and threshing. At harvest, the sales that were made from the harvested seeds (returns) were also obtained and benefit was calculated thus: Benefit $=$ Returns - Cost.

\section{Results and Discussion}

\subsection{Effects of Sowing Date Experiment}

The results (Table1) showed that there was no significant difference in the number of insects/plant among the different sowing dates $(\mathrm{P}>0.05)$. However, the number of insects/plants was relatively lower in sunflower sown on $5^{\text {th }}$ July and higher on those sown on $12^{\text {th }}$ July than those sown on other dates. Percent incidence of infestations of infestations was significantly higher in sunflower sown on $5^{\text {th }} \mathrm{July}$ than on $26^{\text {th }} \mathrm{July}$. However, the incidence of infestation decreased in the subsequent sowing dates after $5^{\text {th }}$ of July. The higher number of insects per plant in sunflower sown after $5^{\text {th }}$ July may have been due to the fact that insect may have migrated between crop fields. Migration of insects pest from one field to the other to find new succulent plants to feed on is common (Pedigo, 2002; Dhaliwal \& Arora, 2006).

Table 1. Number of Pachnoda interrupta/plant and percentage incidence of infestation in sunflower at Maiduguri, during the 2007 cropping season

\begin{tabular}{ccc}
\hline Treatments & Mean number of insects/plant & Mean \% incidence of infestation \\
\hline $5^{\text {th }}$ July & 1.18 & 21.87 \\
$12^{\text {th }}$ July & 1.35 & 17.45 \\
$19^{\text {th }}$ July & 1.20 & 11.46 \\
$26^{\text {th }} \mathrm{July}$ & 1.21 & 7.16 \\
SE \pm & 0.14 & 3.47 \\
LSD $(\mathrm{P}<0.05)$ & 0.45 & 10.9 \\
F values & 0.018 & 0.021 \\
\hline
\end{tabular}

The result in Table 2 shows that there was significantly $(\mathrm{P}<0.05)$ lower damage on sunflower sown on $19^{\text {th }}$ than those sown on $5^{\text {th }}$ July. Delaying planting dates is therefore, useful as a strategy for reducing P. interrupta damage on sunflower. This is probably, the first report documenting the impact of delayed planting in reducing damage by $P$. interrupta. However, Knodel et al. (2011) reported similar findings for damage ratings on sunflower from Neotephiritids finalis and Suleima heliathana. This implies that, the use of appropriate planting date can reduce $P$. interrupta injury on sunflower in Maiduguri. It further suggest that $19^{\text {th }}$ July is the most appropriate date for sunflower planting to reduce damage ratings by $P$. interrupta in this study area and other similar ecologies.

The percentage damage of sunflower by $P$. interrupta decreased on sunflower sown on $5^{\text {th }}$ through $19^{\text {th }}$ July. However, damage slightly increased on the $26^{\text {th }}$ July compared to damage on $12^{\text {th }}$ and $19^{\text {th }}$ July. These results appear contrary to the report that, late planting date is a viable pest management strategy for mitigating economic damage caused by important sunflower head-feeding insect pests (Knodel et al., 2011). It could be due to population build up as the season grows or as a result of migration and aggregation of individual from previous planting dates as successional planting prolongs the risk of infestation (Stoll, 2005) and by extension the degree of damage. Insects are also known to change their orientation towards a particular host when it reached certain stages that are not palatable (Pedigo, 2002; Dhaliwal \& Arora, 2006). Grain yield loss was significantly higher in sunflower sown on 26 than on $12^{\text {th }}$ July. Grain yield was however, highest in sunflower sown on the $5^{\text {th }}$ of July, perhaps due to regeneration and compensation of the grain damaged early the stages of crops life. The phenomenon of yield compensation has been reported in many crops (Sastawa \& Lale, 2000).

Generally, the manipulation of planting date helps to minimize pest damage by producing asynchrony between host plants and the pest or synchronizing insects' pests with their natural enemy or presence of alternative hosts of the pest (Dhaliwal \& Arora, 2006). Teetes (1993) reported a different outlook to the use of planting date as 
being useful in that, suitable hosts were not available until most of the overwintering pests adults emerged and died. However, the most plausible conclusion for this particular study is that, the slight increase in damage is as a result of migration of $P$. interrupta adult from other crops especially Pearl Millet that is widely cultivated in Maiduguri, and is also noted to be its host (Sastawa et al., 2011).

Table 2. Percentage damage and grain yield loss in sunflower from P. interrupta at Maiduguri during the 2007 cropping season

\begin{tabular}{cccc}
\hline Treatments & Mean \% damage & Mean \% grain yield & Grain yield $(\mathrm{Kg} / \mathrm{ha})$ \\
\hline $5^{\text {th }}$ July & 13.00 & 13.02 & 805.56 \\
$12^{\text {th }}$ July & 7.82 & 5.82 & 591.67 \\
$19^{\text {th }}$ July & 6.31 & 12.85 & 500.00 \\
$26^{\text {th }}$ July & 8.05 & 22.96 & 291.11 \\
SE \pm & 1.68 & 8.15 & 146.91 \\
LSD $(\mathrm{P}<0.05)$ & 3.45 & 5.92 & 467.17 \\
F values & 0.011 & 0.021 & 0.024 \\
\hline
\end{tabular}

\subsection{Economic Threshold Level Experiment}

The result (Table 3 ) for yield for infestations at the flowing stage shows that there was no significant differences $(\mathrm{P}>0.05)$ between the yields of flowers infested with one adult $P$. interrupta and control $(0$ adults). Both treatments however, yielded significantly higher $(\mathrm{P}<0.05)$ than all the remaining treatments whose yield differences were found not to be statistically significant $(\mathrm{P}>0.05)$.

The results for damage for flowering stage infestations (Table 3) indicate that, damage for control plots were significantly $(\mathrm{P}<0.05)$ lower than all other treatment. Similarly, the damage from plots infested with one adult $P$. interrupta was significant $(\mathrm{P}<0.05)$ lower than those of other treatments whose differences did not indicate any statistical significance $(\mathrm{P}>0.05)$ excepting the control.

Table 3. Mean yield and damage at flowering stage

\begin{tabular}{cccc}
\hline & & \multicolumn{2}{c}{ Mean \pm S.E. } \\
\hline Treatment & Number inoculated & Yield & Damage \\
\hline T1 & 1 & $5.6 \pm 0.13$ & $4.77 \pm 1.36$ \\
T2 & 2 & $3.71 \pm 0.31$ & $9.44 \pm 0.18$ \\
T3 & 3 & $3.99 \pm 0.51$ & $9.58 \pm 0.14$ \\
T4 & 4 & $3.84 \pm 0.87$ & $9.78 \pm 0.21$ \\
T5 & 5 & $3.84 \pm 0.75$ & $9.69 \pm 0.03$ \\
T6 & 0 & $6.84 \pm 0.84$ & $1.00 \pm 0.0$ \\
& LSD $(\mathrm{P}<0.05)$ & 1.95 & 1.75 \\
& F values & 0.020 & $<0.001$ \\
\hline
\end{tabular}

The results for damage for infestations at the milky grain stage (Table 4) indicate that, there was no significant $(\mathrm{P} \geq 0.05)$ difference between damage recorded on plots infested with 3 and 5 adults $P$. interrupta, but the damage recorded on other plots excepting the control plots are statistically similar $(\mathrm{P} \geq 0.05)$. However, as expected, significantly $(\mathrm{P} \leq 0.05)$ least damage was recorded on the control plots ( 0 adults). While the results for yields for infestations at the milky grain stages were not significantly $(\mathrm{P} \geq 0.05)$ different from each other (Table 4). This indicated there was a kind of yield compensation due to expansion of the grain sizes of the sunflower seeds to replace the adjacent voids created by the $P$. interrupta feeding (Dent, 1991). 
Table 4. Mean yield and damage at milky stage

\begin{tabular}{cccc}
\hline & & \multicolumn{2}{c}{ Mean \pm S.E. } \\
\hline Treatment & Number inoculated & Yield & Damage \\
\hline T1 & 1 & $4.08 \pm 1.32$ & $2.58 \pm 1.0$ \\
T2 & 2 & $5.35 \pm 1.05$ & $2.46 \pm 0.77$ \\
T3 & 3 & $3.09 \pm 1.02$ & $5.65 \pm 2.37$ \\
T4 & 4 & $5.94 \pm 2.03$ & $2.74 \pm 0.69$ \\
T5 & 5 & $2.71 \pm 0.85$ & $7.46 \pm 1.15$ \\
T6 & 0 & $5.99 \pm 0.24$ & $1.00 \pm 0.0$ \\
& LSD (P<0.05) & 3.73 & 3.78 \\
& F values & 0.286 & 0.026 \\
\hline
\end{tabular}

\subsection{Gain Threshold}

Table 5 shows the gain threshold and economic injury level for the control of P. interrupta on sunflower in Maiduguri in 2007 cropping season. At the flowering stage, the economic injury level was 2.38 beetle/plant while the gain threshold was $13.83 \mathrm{~kg} / \mathrm{ha}$. At milky grain stage, the economic injury level was 2.36 beetle/plant and the gain threshold was the same as that of the flowering stage. The amount of grain loss/insect at flowering stage was $5.88 \mathrm{~kg}$ while that of the milky grain stage was $5.85 \mathrm{~kg}$.

Table 6 shows the gross margin analysis for the production of sunflower infested by P. interrupta in Maiduguri in 2007. Ratio of cost to benefit of sunflower production was 1:4.9 units. This implies that for every unit of input the farmer may reap 4.9 units of output (benefit). This ratio can be translated into percentage to mean that a farmer may enjoy $20 \%$ benefit over cost of production per ha (Table 6). This means that there is clear benefit to the farmer when he intervenes artificially to counteract the deleterious effect of this pest in Maiduguri as 1:1 cost: benefit ratio is established to be the action threshold for all agricultural pests (Kumar, 1984; Gullan \& Cranston, 1994; Pedigo, 2000; Norris et al., 2002; Lale, 2002; Dhaliwal \& Arora, 2006).

Table 5. Grain threshold and economic injury level for P. interrupta control on sunflower control in Maiduguri, 2007 cropping season

\begin{tabular}{ll}
\hline Stage of plant growth/parameters & Values \\
\hline Flowering stage & \\
Economic injury level & 2.38 beetles/plant \\
Gain threshold & $13.83 \mathrm{~kg} / \mathrm{ha}$ \\
Regression equation of number of insect (x)and yield (y) & $\mathrm{y}=37.39-5.88 \mathrm{x}$ \\
Milky grain stage & \\
Economic injury level & 2.36 beetles $/$ plant \\
Gain threshold & $13.83 \mathrm{~kg} / \mathrm{ha}$ \\
Regression equation of number of insect (x)and yield (y) & $\mathrm{y}=41.26-5.84 \mathrm{x}$ \\
\hline
\end{tabular}

Note: cost of insecticides $=\mathrm{N}-2,075 /$ ha; Selling price of $1 \mathrm{~kg}$ of sunflower seeds $=\mathrm{N}-150.00$ in 2007. $\mathrm{N}=\mathrm{Naira}$ and one naira $=0.00625$ USD.

The economic injury level for both flowering and milky grain stages is about 2 beetles/plant. Since the economic threshold (action threshold) is normally lower than the economic injury level EIL (Pedigo, 2000; Lale, 2002; Norris et al., 2002; Obeng-ofori \& Afre-Nuamah, 2007), the results suggest that control of P. interrupta on sunflower at both the flowering and milky grain stages should begin when the population is about 1.9 beetles/plant or lower. Treatment at this level of infestation could be accompanied by $20 \%$ benefit/plant for two sprays each at flowering and milky grain stages. However, this will vary depending on the cost of equipment, insecticides and value of the crop product in a growing season and the functional interrelationships of other 
climatic factors that influence the performance of sunflower as a crop and P. interrupta as a pest (Gullan \& Cranston, 1994; Dhaliwal \& Arora, 2006). Pest control advisers and farmers should study the relationships between these factors in a sunflower enterprise before commencing any pest control strategy. The above finding should however, serve as a guide to curtail damage by this pest in the study area.

Table 6. Gross margin (cost-benefit) analysis for the production of sunflower infested by $P$. interrupta at Maiduguri in 2007

\begin{tabular}{|c|c|c|}
\hline Starting inventory & & Ending inventory \\
\hline Man days in naira $(\mathrm{N}) / \mathrm{ha}$ & & Yield $=804.70 \mathrm{~kg} / \mathrm{ha}$ \\
\hline Land preparation & 2,000 & Sales $=$ N120, 705 \\
\hline Seeds & 1,000 & (a) $\mathrm{N} 150 / \mathrm{kg}$ \\
\hline Weeding $5 \times 2$ & 4,000 & \\
\hline Fertilizer 5bags @N1,800 & 9,000 & \\
\hline Harvesting & 2,000 & \\
\hline Threshing & 2,000 & \\
\hline Insecticides (x 2 spraying) & 4,150 & \\
\hline Total & $\mathrm{N}-24,150$ & $\mathrm{~N} 120,705$ \\
\hline Cost: benefit $=\mathrm{N} 24,150: \mathrm{N} 120,705$ & & \\
\hline
\end{tabular}

One man days is 5 hrs @ $\mathrm{N} 400.00$.

$\mathrm{N}=$ Naira and one naira $=0.00625 \mathrm{USD}, @=$ at the price rate of.

\section{Conclusion}

It was evident from the results of these studies that sowing date has some effect on sunflower yield in the face of damage by $P$. interrupta, and $19^{\text {th }}$ of July is found to be the best planting date for the management of infestation of this pest in Maiduguri and indeed other similar ecologies. It was equally clear that the economic injury level is for both infestation at the flowering and milky grain stages are similar and controls measures needs to be initiated when there are on the average 2 beetles/plant. The profitability of sunflower productions in the face of $P$. interrupta infestations is guaranteed when control measures are implemented at the above economic threshold level. When farmers adhere to the above, a cost: benefit ratio of 1: 4.9 is sure bait to them provided that the cost of equipment, insecticides and value of the crop product in a growing season remains constant. Resource-poor farmers therefore can easily utilize this cultural control strategy in enhancing their productivity in sunflower production in this region by providing assurance against $P$. interrupta damage.

\section{Reference}

Abdou, S. M. M., Abd El- Latif, K. M., Farrag, R. M. F., \& Yousef, K. M. R. (2011). Response of Sunflower Yield and Water Relations to Sowing Dates and Irrigation Scheduling Under Middle Egypt Condition. Advances in Applied Science Research, 2 (3), 141-150.

Bamgboye, A. I., \& Adejumo, A. O. D. (2007). Development of a Sunflower Oil Expeller. Agricultural Engineering International: the CIGR Ejournal.

Dhalilwal, G. S., \& Arora, R. (2006). Integrated Pest management. (p. 369). New Delhi- India: Kalyani Publishers.

Dent. (1991). Insect pest management. (p. 604). CAB International.

FAO. (1972). Food and Agricultural organization. Annual production year book.

Garret, C. G. (1978). New fertility restoration Genes from sunflower for sunflower PETI male sterile cytoplasm. Geographical journal, 22(2), 94-105.

GENSTAT. (2007). GENSTAT statistical packages GenStat Release 9.2 (PC/Windows) (9th ed.). Lawes Agricultural Trust, Rothamsted Experimental Station, UK.

Gullan, P. J., \& Cranston, P. S. (1994). The insects: An outline of Entomology. London, UK: Champman and 
Hall.

Knodel, J. J., Ganehiarachchi, G. A. S. M., Patrick B. B., Anitha, C., \& Laurence, D. C. (2011). Impact of Planting Dates on a Seed Maggot, Neotephritis finalis (Diptera: Tephritidae), and Sunflower Bud Moth (Lepidoptera: Tortricidae) Damage in Cultivated Sunflower. Journal of Economic Entomology, 104(4), 1236-1244. http://dx.doi.org/10.1603/EC11012

Kumar, R. (1984). Insect pest control with specific reference to African Agriculture. (p. 298). London: Edward Arnold.

Lale, N. E. S. (2002). Stored product entomology and Acarology in tropical Africa (1st ed.). Mole publication Ltd Maiduguri-Nigeria.

Norris, R. F., Caswell-Chen, E. P., \& Kogan, M. (2002). Concepts in integrated pest management. New Delhi: Prentice-Hall of India PVT Ltd.

Obeng-Ofori, D., \& Afre-Nuamah, K. (2007). Crop pests and pest management. In D. Obeng-Ofori (Ed.), major pests of food and selected fruits and selected crops in Africa (pp. 1-46). Accra- Ghana: City printers ltd.

Ohlson, I. S. R. (1992). Modern processing of rapeseed. Journal of the American Oil Chemists' Society, 69, 195-198.

Pedigo, L. P. (2002). Entomology and pest management (4th ed.). Prentice Hall, Upper Saddle River, NJ.

Sastawa, B. M., \& Lale, N. E. S. (2000). Efficacy of host plant resistance, sowing date mordifications and intercropping as methods for the control of Pachnoda interrupta (Olivier) in Pearl Millet in the Nigerian Sudan Savanna. Journal of Arid Environment, 46, 249-262. http://dx.doi.org/10.1006/jare.2000.0671

Sastawa B. M., Isah, M. D., Abdullahi, G., \& Sule, H. (2011). Panicle insects pests of of Millet in Maiduguri, Nigerian sudan savanna, farmers perception, relative abundance and associated grain yield. Journal of Arid Agriculture, 20, 130-139.

Stoll, G. (2005). Natural crop protection in the tropics. Weikersteim: Margraf publishers.

Teetes, G. T. (1993). The environmental control of insects using planting times and plant spacing. In D. Pintel (Ed.), CRC Handbook of pest management in Agriculture (pp. 169-182). New Delhi: CBS publishers and Distributors.

Univ. penn. (2000). Ethiopian humanitarian organization. (p. 36). Univ. of Penn. African Studies Centre press.

Waalwijk, \& Von Dorn, J. J. L. (1989). Sunflower Roles in Developing Countries. Sunflower news letter, 2, 5-7.

Yoyock, J. Y., Lombia, G., \& Owonubi, J. J. (1988). Crop Science and Production in WarmClimates. Macmillan Intermediate Agricultural Series, London. 